\title{
THE LINING EPITHELIUM OF THE INTRAPULMONARY AIRWAYS IN THE ONE-HUMPED CAMEL (Camelus dromedarius) LIGHT AND SCANNING ELECTRONE MICROSCOPIC STUDIES
}

\author{
Fatimah A. Alhomaid \\ Department of Biology - College of Science and Arts, Al-Qassim University, Saudi \\ Arabia.
}

\begin{abstract}
The mucosa of the intrapulmonary airways of the one-humped camel was mainly formed of the usual ciliated columnar cells, basal cells, goblet cells, brush cells and the non-ciliated cells of Clara. Basal cells and goblet cells, were found only in large airways and were scarce or absent in the bronchiolar epithelium. Brush cells were rarely found in-between the bronchiolar epithelium. The nonciliated Clara cells were the prominent cell-type in the lining epithelium as far distally as terminal and respiratory bronchioles.
\end{abstract}

Key words: Dromedary camel, Lung, Bronchiole, Clara cell, Brush cell, Intrapumonary airways

\section{INTRODUCTION}

Camels are well known for their positive desert characteristics. This has urged many scientists and researchers to study the biology of this organism in details. The respiratory tract of camel has attracted considerable interest. A feature of their nostrils is that a large amount of 
water vapor in their exhalations is trapped and returned to the camels body fluids, thereby reducing the amount of water lost through respiration. The available information is fragmentary (Kikkawa and spiltzer 1968). Some discrepancies were found between an early description of the respiratory tract of camelus dromedarius by (George 1951, Osman, 1974 and Tayeb, 1964) and more recent study (Zaghloul, 2004). In an attempt for better understanding of the structure-function relationships in the lung of the one-humped camel. Our objective was to study the ultrastructure morphology of the epithelial lining of the intrapulmonary airways, using both TEM and SEM.

\section{MATERIAL AND METHODS}

The lungs of 9 apparently normal one-humped camels of both sexes were used. Samples were taken from different areas of the apical and cardiaco-diaphragmatic lobes of both lungs. Samples of lung tissue were fixed in $10 \%$ buffered formalin before embedding in paraffin. Sections, $4-6 \mathrm{Um}$, thick were cut and stained with hematoxylin and eosin and Crossmon's trichrome stains. As outlined by Bancroft and Stevens (1990). For SEM other small strips of lung tissue were fixed in glutaraldehyde, dehydrated in a graded series of ethanol and then critical point dried from liquid $\mathrm{CO}_{2}$. The blocks were mounted on carbon disks with adhesive, and coated with a thin (50A) layer of gold in a cool-triode sputtercoater. The tissue blocks examined with a JEOL JSM35 electron 
microscope at magnifications ranging from 5,000 to 20,000X.

\section{RESULTS}

\section{Light microscopy:}

The intrapulmonary bronchi and bronchioles were lined with 5 types of cells; ciliated cells, goblet cells, brush cells, basal cells and Clara cells. The ciliated and basal cells were the most numerous cell types.

\section{Structural features of the lining cells:}

The ciliated cells appeared as tall columnar and having large number of long cilia (Fig.1\&2). Their nuclei were large oval to ovoid in shape and were basally located but mostly towards the apical half. The chromatin was condensed on the inner surface of the nuclear envelope. The cytoplasm was pale.

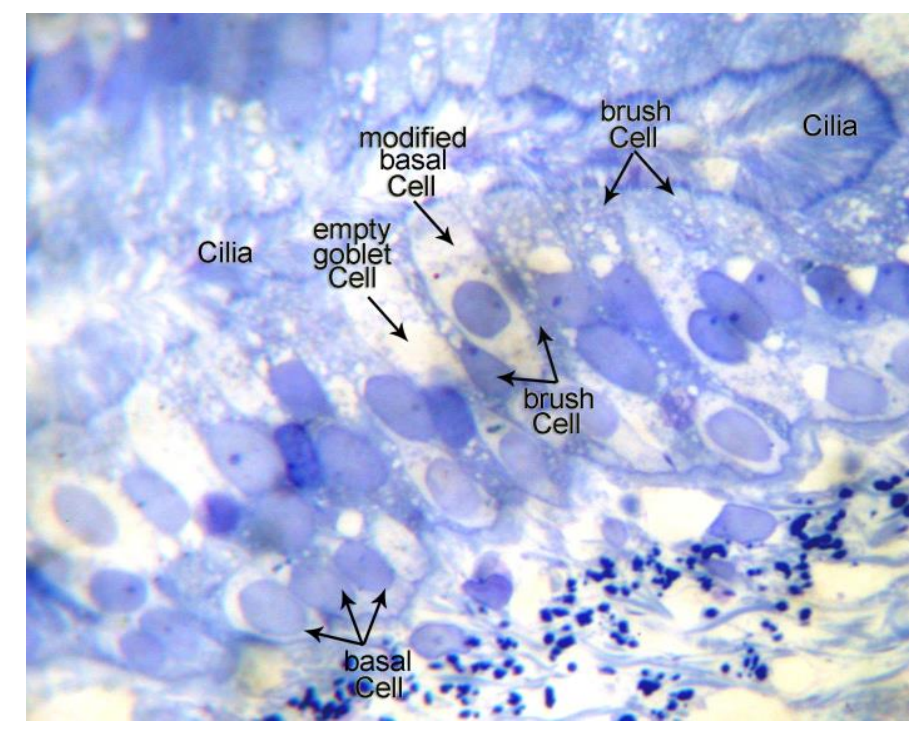

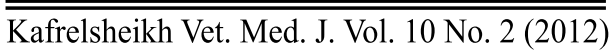


Fig. (1): Bronchial epithelium of camel's lung. Semithin sections - Toluidine blue, X 800

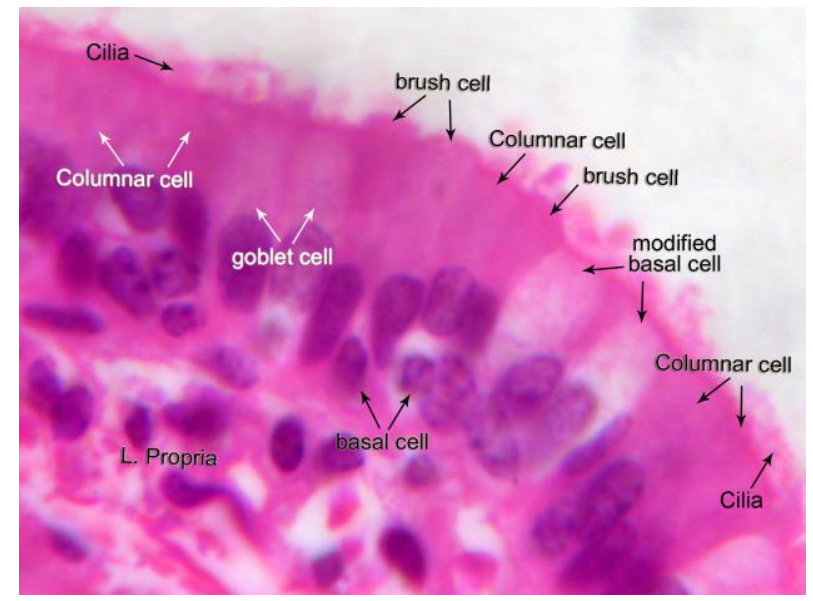

Fig. (2): The mucosa of an intrapulmonary bronchus of camel's lung. H\&E stain, X800

The goblet cells were found only in large airways and were scarce or absent in the bronchiolar epithelium. Goblet cells occurred singly or in groups of 2 or 3 cells in- between the columnar ciliated ones (Fig.3\&4). Their nuclei were often crescent shaped and found in the narrow stem basal portion. The wide apical portion of the cells was occupied by vacuoles which varied in density. 
Fig. (3): Mucosa of intrapulmonary Bronchus H\&E stain, X 800

The brush cells were seen more often in the proximal bronchioles. They were distributed sparsely but rather uniformly, and tend to be grouped in two or more cells. Each cell appeared narrow columnar in shape and lacking any cilia (Fig. 3\&5). They were immediately recognized by their apical vacuolated dense cytoplasm. The nucleus was elongated or oval and occupying a middle position.

In the bronchial airways, the brush cells constituted a faire amount (more or less 20\%) of the total cell population. Whereas in the bronchiolar tree, they were rarely found and were less than $10 \%$ of the total cell population.

The basal cells were smaller in diameter and were seen resting on the basement membrane, but not approaching the luminal border. They had different shapes with large oval or spherical centrally located nuclei and unstained cytoplasm (Fig.1\&3).

Their cytoplasm was lightly stained. Some basal cells attained a larger size and became insinuated in-between the other lining cells to 
reach the luminal surface. It could be suggested that the basal cells functioning to replace apoptotic columnar, goblet and brush cells.

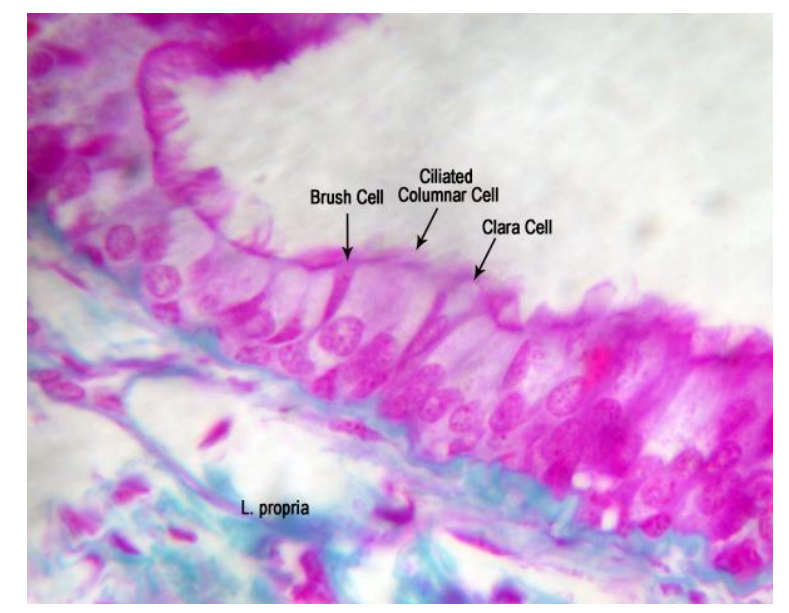

Fig. (4): The epithelial lining of the proximal bronchiole. Crossmon's trichrome stain, X 800

The Clara cells were numerous and prominent in the lining epithelium as far distally as terminal and respiratory bronchioles. They appeared as non-ciliated columnar cells with dome-shaped protrusions. They protruded considerably into the lumen far beyond the apices of the adjacent ciliated cells. So that the apical surface of the epithelial lining the bronchiole showed cilia and dome-shaped protrusions of the Clara cells. The nucleus was large but had no remarkable features.

$\overline{\overline{\text { Kafrelsheikh Vet. Med. }}}$

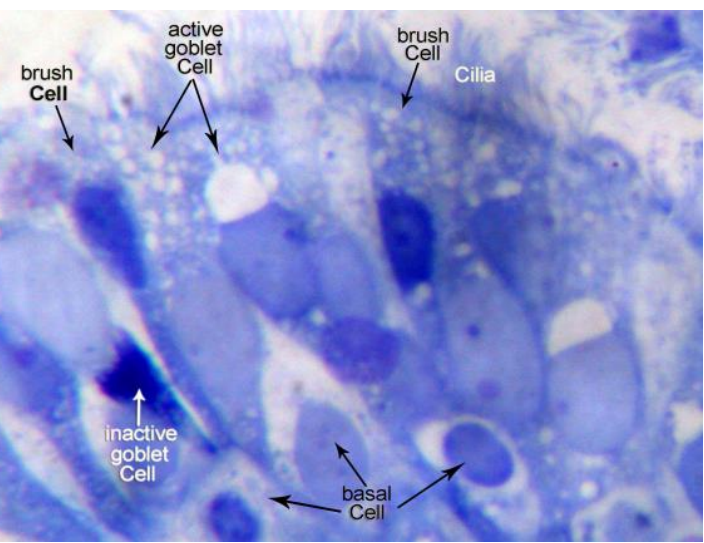


Fig. (5): Semithin section of bronchiolar epithelium. Toluidine blue, X 800

As the caliber of the airway diminished, the lining columnar cells of the bronchi became shorter with the goblet cells tended to be sparse. The Clara cells within the epithelial lining became more obvious and numerous.

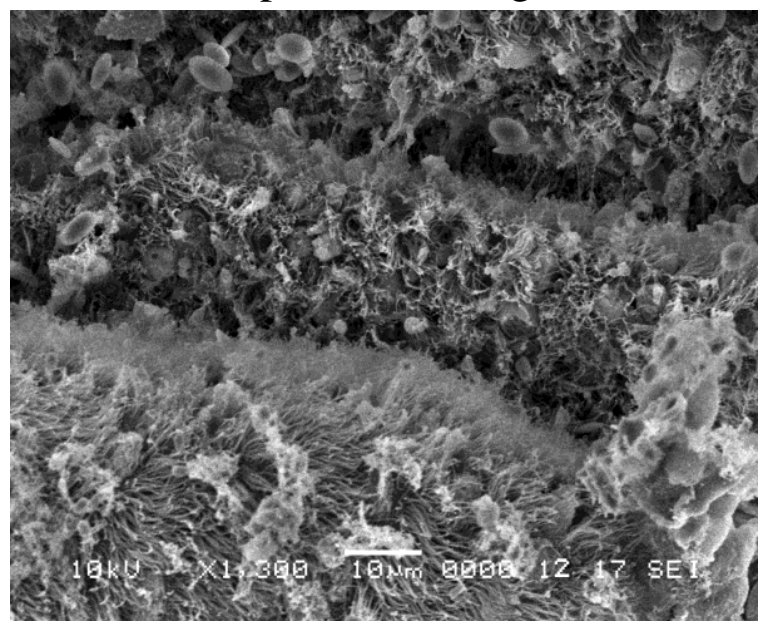

Fig. (6): Bronchial mucosa thrown into longitudinal folds.

\section{Scanning electron microscopy:}

Bronchi: The mucosa of the bronchi was thrown into regular longitudinal folds with transverse furrows in-between (Fig. 6). The majority of the lining cells appeared as columnar ciliated bearing abundant long cilia (Fig. 7). Goblet cells were seen bulged into the lumen, each with dome-shaped apical end. The bronchial epithelium was resting on an interrupted basement membrane (Fig.8).

Bronchioles: These airways had a small diameter and their wall was uninterrupted by alveoli. A bronchiole split up into terminal 
bronchioles and then respiratory bronchioles that were connected to the alveolar sacs by alveolar ducts. The mucosa showed a scalloped appearance and was thrown into folds separated from one another by deep furrows.

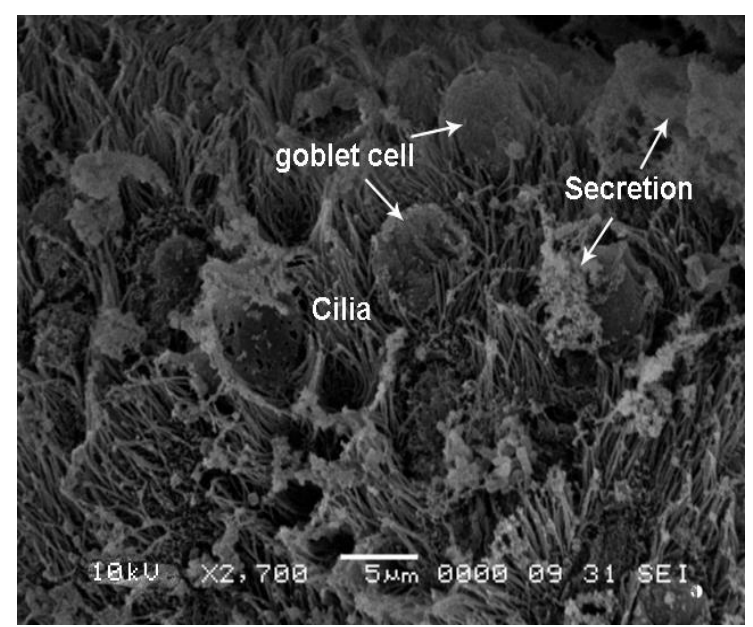

Fig. (7): The lining epithelium of the Bronchus. The columnar ciliated are the predominant cells.

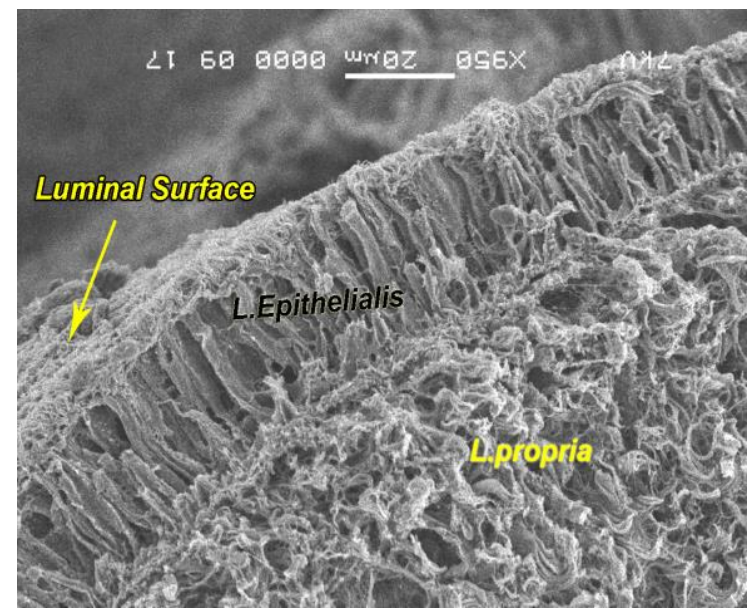

Fig. (8): Bronchial epithelium is resting on an uninterrupted basement membrane.

In large bronchioles, the epithelium was usually columnar ciliated with few non-ciliated cells of Clara (Fig. 9). The length of the cilia was uniform, approximately 4.5 to $5 \mu \mathrm{m}$. The secretory materials appeared as Kafrelsheikh Vet. Med. J. Vol. 10 No. 2 (2012) 
small granules within the apical cytoplasm of Clara cells (Fig. 10). In small bronchioles, the ciliated cells arranged in groups interspersed with Clara cells throughout the epithelial surface. The length of the cilia was also uniform. These microvilli were not pronounced throughout the mucosal surface.

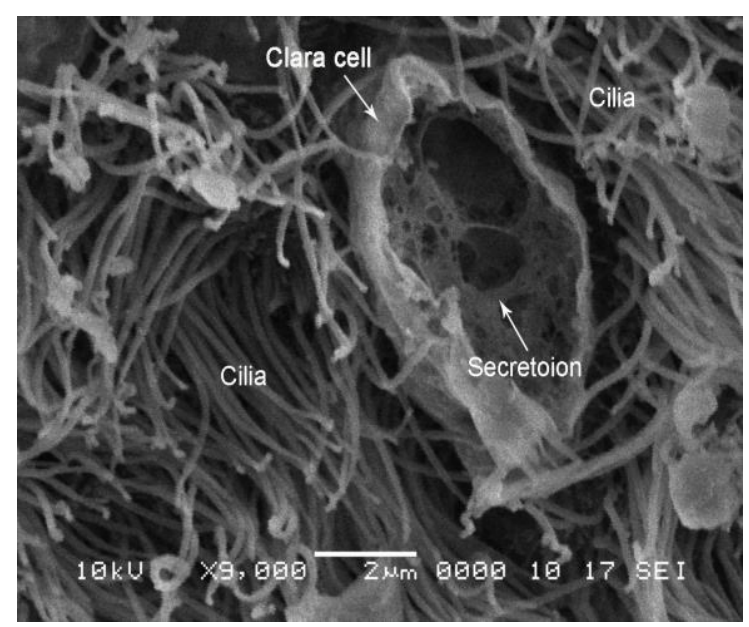

Fig. (9): Epithelium lining of the bronchiole

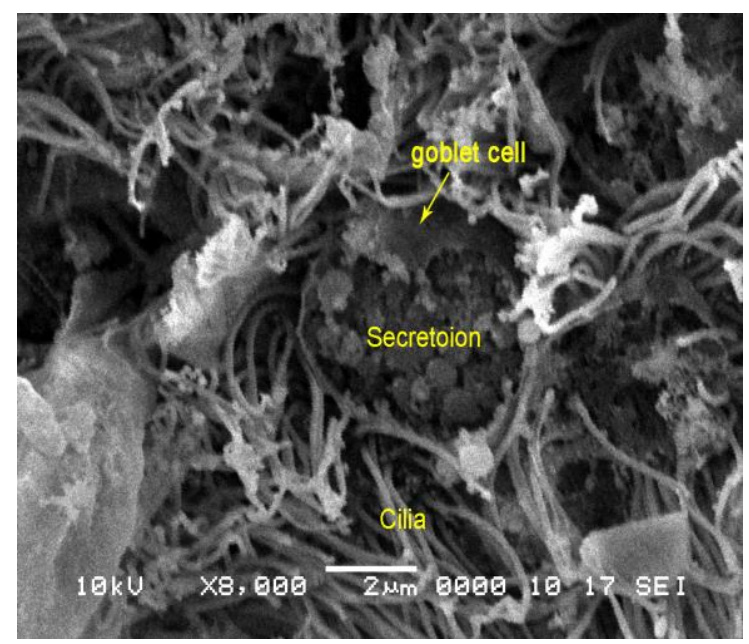

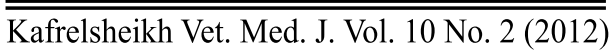


Fig. (10): Bronchiolar mucosa formed of columnar ciliated with secretory cells of Clara. The secretory materials appeared as small granules within the apical cytoplasm of Clara cells.

The terminal bronchioles were lined by both ciliated cells and Clara cells (Fig. 11). In their proximal portions the ciliated cells predominated. More distally, the ciliated cells became less numerous and were replaced, in some areas, by the Clara cells. The luminal surface of the dome-shaped protrusions of Clara cells was ruptured and showed numerous secretory granules. Down in the bronchiole, the epithelium continued to be composed of both ciliated cells and Clara cells. However, the ciliated cells became appreciably reduced in number (Fig. 12).

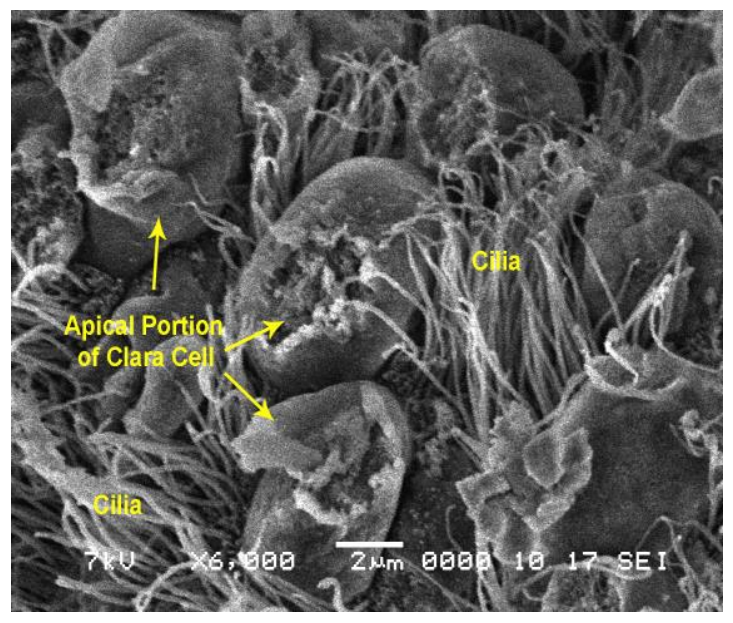

Fig. (11): Epithelial lining of the terminal bronchiole. It shows both ciliated and Clara cells.

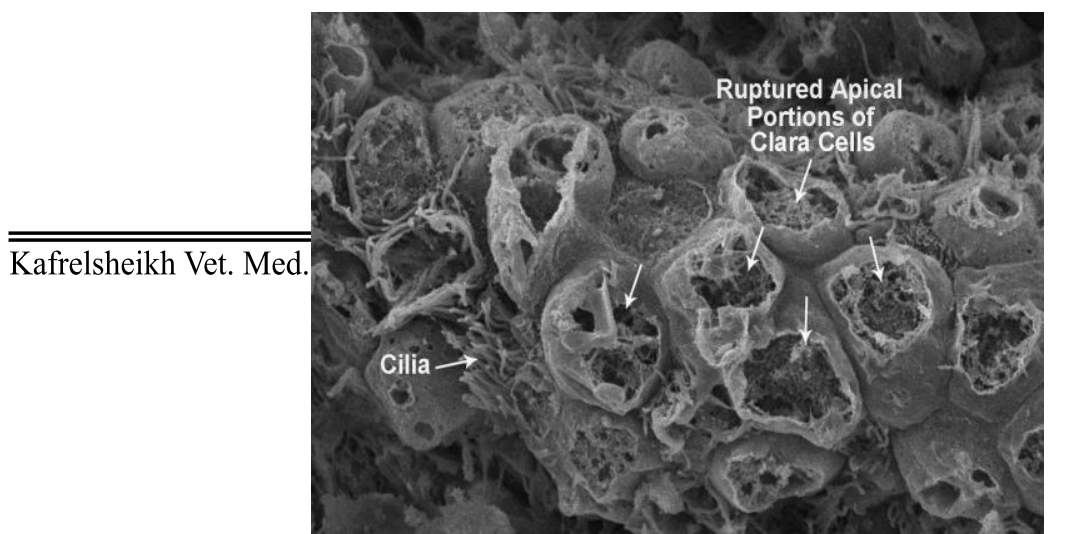


Fig. (12): Terminal bronchiole showing reduced number of the ciliated cells.

In the initial portion of respiratory bronchioles, a transition took place between ciliated and nonciliated Clara cells (Fig. 13).

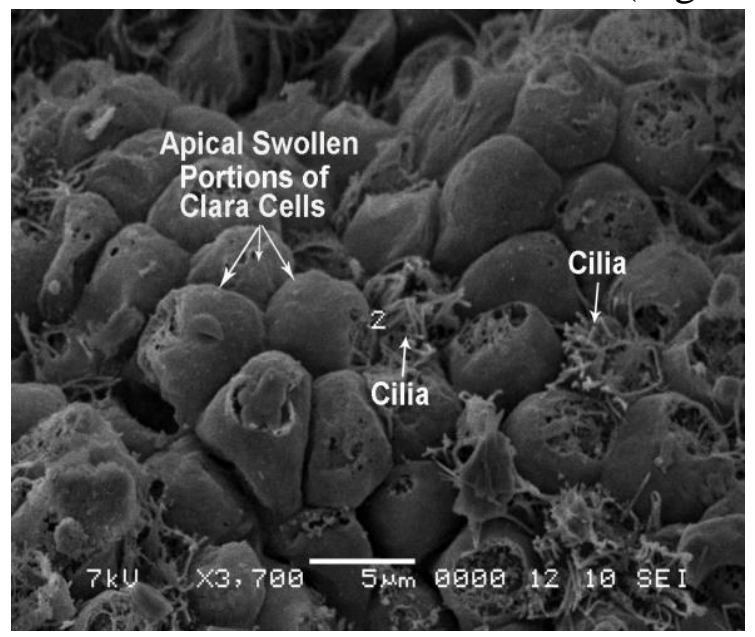

Fig. (13): Epithelial lining the respiratory bronchiole. It shows transition between ciliated and Clara cells.

Past this transition point, only the Clara cells predominated. This transition was usually gradual in camel's lung. More distally in respiratory bronchioles, the lining cells were partially replaced by flat epithelium. The ciliated cells were no longer present except for irregular patches interrupting the dome-shaped protrusions of the Clara cells.

\section{DISCUSSION}

$\overline{\text { Kafrelsheikh Vet. Med. J. Vol. } 10 \text { No. } 2 \text { (2012) }}$ 
Schmidt-Nielsen (1999) stated that the nasal and respiratory passages of the camel are lined with hygroscopic mucus, which dries out when the animal breathes in and then recovers moisture from expired air, thus considerably reducing insensible losses of water. According to Rubin (2002), the secretory product of the goblet cells of the airway surface epithelium and the submucosal glands constituting the airway mucus. It is a viscoelastic gel containing water, carbohydrates, proteins, and lipids. It is extremely important for airway integrity and pulmonary defense. It also protects the epithelium from foreign material and from fluid loss. The author added that Mucus is transported from the lower respiratory tract into the pharynx by air flow and mucociliary clearance. In the present study, the surface features of the normal distal respiratory tract of the camel have been described. The mucosa of the intrapulmonary airways was mainly formed of the usual ciliated columnar cells. Basal cells and goblet cells, were found only in large airways and were scarce or absent in the bronchiolar epithelium. The non-ciliated Clara cells were the prominent cell-type in the lining epithelium as far distally as terminal and respiratory bronchioles. Brush cells were rarely found in-between the bronchiolar epithelium.

The intrapulmonary bronchi were densely carpeted with ciliated cells. Mucus secreting cells protruded between the cilia and were more numerous in the bronchi. These findings are in accord with features observed in cattle (lovannitti et al. 1985), dogs (Wright et al.1983,Magjid 1986) cats (Tandler et al. 1983a) and non-human primates (Wilson et al. 1984 and Maina 1988). In some examined bronchi there were occasional small irregular patches of non-ciliated 
microvillus cells. Similar patches have been described in adult cattle (lovannitti et al. 1985). According to Pirie et al., (1990) these were considered to be abnormal and possibly represented the result of an earlier subclinical infection.

Although ciliated cells were the most numerous cell type in the small bronchi, goblet cells became more evident. The latter were either flat or bulged into the lumen; others were discharging mucus and appeared similar to the mucus secreting goblet cells described in the bronchi of rat (Andrews 1979 and 1974) and hamster (Becci et al. 1978).

In the bronchioles, ciliated cells gradually became less numerous and the non-ciliated cells became the predominant cell type in the terminal bronchioles. This is in accord with the findings of Plopper (1983) who stated that they form up to 75 per cent of the epithelial population of bronchioles in the horse.

The present study revealed that the percentage of the ciliated cells to the whole epithelial lining cells was constant in the intrapulmonary bronchi (35\%) and in the bronchioles (70-80\%). However, Jeffery and Reid (1975) reported 35\% ciliated cells in the main bronchi in rat. This finding seems to correspond to the report by (Andrews 1979) who mentioned that areas populated with few ciliated cells are occupied by goblet cells.

An interesting observation was the gradual junction between respiratory bronchioles and alveolar ducts. Both ciliated cells and nonciliated bronchiolar epithelial cells extended to, and were contiguous with, the cells of the alveolar epithelium. In horse, this change was

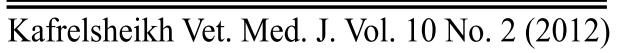


abrupt (Pirie et al. 1969) and was gradual in dog where only nonciliated bronchiolar epithelial cells extend to the junction with the alveoli of the respiratory bronchioles (Wright et al.1983). This change was also described as being poorly developed in the horse (Nowell, and Tyler 1971 and Tyler et al. 1971). Smith et al., (1979) and Plopper et al., (1980) demonstrated in the rat bronchioles that the Clara cells projected their entire apical surface high above the surrounding ciliated cells. On the other hand, Andrews (1974) described the Clara cells in rat bronchioles as knobby-surfaced. The present study, however, showed both surface structures of Clara cells in the camel bronchioles. The various surface structures may possibly reflect differences in active secretory phases or cell maturation. Moreover, the distribution of these cells varies. Jeffery and Reid (1975) briefly noted that the cells were located proximally as far as the hilum of the lung. The present study, however, demonstrated that the Clara cells occurred distal to the furcations of the bronchi into bronchioles. Clara (1937) was suggested that the presence of this cell type was characteristic of the terminal bronchioles. In the present study Clara cells were found in airways as far proximally as the hilum. In other species cells with features of the Clara cell have been described as far centrally as the trachea (Hansell and Moretti 1969) and even the nasal mucosa (Matulidnis and Parks 1973). Whether it is the Clara cell or the type-II alveolar cell which contributes most to the surfactant lining of the lung is not yet established (Meyrick and Reid 1973). If the Clara cell does contribute, it could do so at several airway levels.

The brush cell has not previously been described in the airways of domestic animals (Pirie et al. 1969). The brush cells Kafrelsheikh Vet. Med. J. Vol. 10 No. 2 (2012) 
found in the present study resemble those previously described in rat and pig airways (Rhodin and Dalhamn 1956, Luciano et al. 1968 and Baskerville 1970) and in the alveoli of the rat (Meyrick and Reid 1968). In agreement with the findings of (Meyrick and Reid 1968), the brush cell is a rare cell type in the lung as a whole. But in some locations it represents as much as $10 \%$ of epithelial cell volume, and in others it covers up to $2 \%$ of the airway surface. Although the role of the respiratory brush cells is not understood. The presence of many pinocytotic vesicles at its luminal edge suggests an absorptive function. The densities of brush cells in the trachea and the bronchi found by the current study agree with previous observations (Jeffery and Reid 1975). Luciano et al. (1968) suggested a chemoreceptor function for brush cells based on the observation of synaptic junctions between brush cells and afferent nerves. The prevalent hypothesis on the function of brush cells is that they are related to fluid balance in the lung (Meyrick and Reid 1968). This is mainly because the microvilli of the respiratory brush cells resemble those of the small intestinal cells. The brush cells, as seen presently, are concentrated in the proximal airways rather than in the distal ones. Since the type-II pneumocyte has been implicated in fluid and electrolyte transport the alveolar wall (Goodman and Crandall 1982, Mason et al. 1982, Matthay et al. 1982 and Olver et al. 1981), another absorptive cell would not be required for the gas exchange region. This may explain the lack of brush cells in the distal alveolar region.

Blenkinsopp (1967) has shown that the basal cell layer of the extrapulmonary airway acts in a similar way to the germinal layer of the epidermis, division of its cells giving rise to the more superficial layers. 
In this respect the epithelial lining of the large airways may be regarded as having two compartments, one basally situated and involved with division, the other superficial and involved chiefly with maturation (Jeffery and Reid 1975). In contrast, intrapulmonary airways of the camel, and more especially the distal bronchioles, have effectively no basal cell compartment, the single layer being concerned both with division and maturation.

\section{REFERENCES}

- Andrews, P. M.: The respiratory system. In: (ed. by) G. M. Hodges and R. C. Hallowes: Biomedical research applications of scanning electron microscopy. Academic Press, London, 1979, p. 177-202).

- Andrews, P. M.: A scanning electron microscopic study of the extrapulmonary respiratory tract. Amer. J. Anat. 139,1974, 399-424.

- Bancroft J.D., Stevens A.: Theory and practice of histological techniques, $3^{\text {rd }}$ ed.

- Baskerville, A.: Ultrastructural studies of the normal pulmonary tissue of the pig. Research in Veterinary Science 11, 1970, 150-155.

- Becci, P. J., McDowell, E. M. and Trump, B. F.: The respiratoryepithelium Il. Hamster trachea, bronchus and bronchioles. J. Nail. Cancer first. 61, 1978, 551-561.

- Blenkinsopp, W. K. (1967). Proliferation of respiratory tract epithelium in the rat. Experimental Cell Research 46, 144-154. 
- Churchill Livingstone, Edinburgh, 1990.

- CLARA, M.: Zur Histobiologie des Bronchalepithels. Zeitschrift fur mikroskopisch-anatomische Forschung 41, 1937, 321-347.

- George, A.N.: The respiratory system in the camel MVSc thesis, Fac. Vet. Med., Cairo Uni. 1951.

- Goodman B.C. and Crandall D.E.: Dome formation in primary cultured monolayers of alveolar epithelial cells. Am. J. Physiol., 243,1982, 96-100.

- Hansell, M. M. \& Moretti, R. L.: Ultrastructure of the mouse tracheal epithelium. Journal of Morphology 128, 1969, 159-170.

- Jeffery, P. K. and Reid L.: New observations of rat airway epithelium: a quantitative and electron microscopic study. J. Anat. 120, 1975, 295-320.

- Kikkawa, Y. and spiltzer, R.: Inclusion bodies of type- II alveolar cells: species differences and morphogenesis. Anat Rec. 163, 1968, 525-542.

- lovannitti, B., Pirie, H. M. mid Wright, N. G.: Scanning electron microscopic study of the lower respiratory tract in calves and adult cattle: Res. vet. Sci. 38, 1985, 80-87.

- Luciano, L., Reale E. and Rusta H.: Uber eine "chemorezeptive" Sinneszelle in der Trachen der Ratte. Z. Zellforsch. Mikrosk. Anat., 85, 1968, 350-375. 
- Maina, J. N.: Morphology and morphometry of the normal lung of the adult Vervet monkey (Cercopithecus Aerhiaps) Am.J. Anat., 183, 1988, 258-267.

- Majid, A.: A Combined Hislologiral. Histoelremicrrl and Scanning Election Mirrnsropirnl Study nf' fhe Canine Respiratory Duct. Ph.D. Thesis, University of Glasgow. 1986.

- Mason, R.J., Williams M.C., Widdicombe J.H., Sanders M.J., Misfeldt D.S. and Berry L.C.: Transepithelial transport by pulmonary alveolar type II cells in primary culture. Proc. Natl. Acad. Sci. USA, 79,1982, 6033-6037.

- Matthay, M.A., Widdicome J.H. and Staub N.C.: Clearance of alveolar fluid in sheep may involve an active ion transport process. Fed. Proc., 41, 1982, 1244.

- Matulidnis, D. H. and Parks, H. F.: Ultrastructural morphology of the normal nasal respiratory epithelium of the mouse. Anatomical Record 175, 1973, 65-84.

- Meyrick, B. \& Reid, L.: Electron microscopic aspects of surfactant secretion. Proceedings of the Royal Society of Medicine 66, 1973, 386-387.

- Meyrick, B., and Reid L.: The alveolar brush cell in rat lung - a third pneumocyte. Ultrastruct. Res., 23,1968, 71-80.

- New Engl J Med 340, 1999, 397-398. 
- Nowell, J. A. and Tyler, W. S.: Scanning electron microscopy of the surface morphology of the mammalian lung. Am. Rev. Rest. Dis. 1113, 1971, 313-328.

- Olver, R.E., Ramsden C.A. and Strange L.B.: Adrenaline-induced changes in net lung liquid volume flow across the pulmonary epithelium of the fetal lamb evidence for active sodium transport. Proc. Physiol. Soc. (Lond.), 319, 1981, 38-39.

- Osman, F.A.: Some anatomical studies on the bronchial tree and pulmonary vessels of the dromedary camel. MVSc. Thesis, FAc. Vet, Med., Cairo University. 1974.

- Pirie, M., Pirie H.M. and Wright N.G.: Scanning electron microscopic study of the equine upper respiratory tract. Equine Vet. J. 22(2), 1990, 338-342.

- Plopper, C. G., Mariassy A. T. and Hill L. H.: Ultrastructure of the nonciliated bronchiolar epithelial (Clara) cell of mammalian lung: 1. A comparison of rabbit, guinea pig, rat, hamster and mouse. Exp. Lung Res. 1, 1980, 139-154.

- Plopper, C. G.: Comparative morphologic features of bronchiolar epithelial cells. The Clara cell. Am. Rev. resp. Dis., 128, 1983, S37-S41.

- Respiratory Car Vol. 47, No 7 , 2002, Page 761.

- Rhodin, J. and Dalhamn T.: Electron microscopy of the tracheal ciliated mucosa in rat. Z. Zellforsh. 44, 1956, 345-412. 
- Rubin B. K. MEngr: Physiology of Airway Mucus Clearance.

- Schmidt-Nielsen K.: The Camel's Nose: Memoirs of a curious scientist

- Smith, M. N., Greenberg S. D. and Spjut H. J.: The Clara cell: A comparative ultrastructual study in mammals. Amer. J. Anat. 155, 1979, 15-30.

- Tandler, B., Sherman, J. M., Boat, T F. and Wood, R. E.: Surface architecture of the mucosal epithelium of the cat trachea: I Cartilaginous portion. Am. J. Anat. 168, 1983a, 119-131.

- Tandler, B., Sherman, J. M., Boat, T. E and Wood, R. E.: Surface architecture of the mucosal epithelium of the cat trachea: I Structure and dynamics of the membranous portion. Am. J. Anat. 168, 1983b, 133-144.

- Tayeb, M.A.F: The respiratory system of the camel. J.Vet. Sci, 1, 1964, 39-61.

- Tyler, W. S. Gillespie, J. R. and Nowell, L A.: Symposium on pulmonary and cardiac function. I. Modem functional morphology of the equine lung. Equine Vet. J., 3, 1971, 84-94.

- Wilson, D. W., Plopper, C. G. and Hyde, S. M.: The tracheobronchial epithelium of the Bonnet monkey (Mocaca rarlinto): A quantitative ultrastructural study. Am. J. Anat. 171, 1984, 25-40. 
- Wright, N. G., Brown, R. M. H., McCandlish, LA. P., Thompson, H. and Comwell, J. H. C.: Patterns of cilia formation in the lower respiratory tract of the dog: A scanning electron microscopic study. Res. Vet. Sci 34, 1983, 340-346.

- Zaghloul, D.: Electron and light microscopical studies on the lung of one humped camel (camelus dromedaries), PhD Thesis, Fac.vet. med., Alexandria university. 2004.

الظهارة المبطنة للمجارى الهو ائية داخل الرئة في الجمل وحيد السنام (الجمل الدروميديرى) دراسات بالمجهر الضوئي و الإلكتروني الماسح

\section{فاطمة عبد الرحمن الحميد}

قسم الأحياء - كلية العلوم والآداب - بريده - جامعة القصيم - المملكة العربية السعودية

تتكون طبقة المخاطية المبطنة للمجارى الهوائية داخل الرئة من خلايا عمادية مهدبه وخلايا قاعدية وخلايا كأسية وخلايا الفرشاه وخلايا كلارا.

كانت الخلايا المهدبه والقاعدية هى الأكثر فى العدد فى ظهارة المجارى الهوائية كبيرة الحجم ،

بينما ظهرت قليلة العدد أو اختقت في ظهارة الثعيبات. أيضاً ظهرت خلايا الفرشاه فى الأجزاء العلوية من الثعب ولكنها كانت نادرة في بطانة الشعيبات. كانت خلايا كلارا هى النوع السائد من خلايا البطانة في الثعيبات الإنتهائية والثتعيات التنفسية. 